Journal of Animal and Veterinary Advances 11 (14): 2409-2416, 2012

ISSN: $1680-5593$

(C) Medwell Journals, 2012

\title{
Effects of Head-Only Electrical Stunning on the Physico-Chemical Characteristics and Desmin Degradation of Broiler Breast Muscles at Different Time Postmortem
}

\author{
${ }^{1}$ M.S. Salwani, ${ }^{1,2}$ A.Q. Sazili, ${ }^{1,3}$ I. Zulkifli, ${ }^{2}$ Z. Nizam and ${ }^{1}$ W. Zul Edham \\ ${ }^{1}$ Halal Products Research Institute, \\ ${ }^{2}$ Department of Animal Science, Faculty of Agriculture, \\ ${ }^{3}$ Institute of Tropical Agriculture, Universiti Putra Malaysia, \\ 43400 UPM Serdang, Selangor Darul Ehsan, Malaysia
}

\begin{abstract}
The study aimed to determine physico-chemical characteristics and myofibrillar proteolysis of breast muscles from broiler chickens subjected to head only electrical stunning. Pectoralis major muscles were collected from un-stunned $(\mathrm{N}=25)$ and electrically stunned $(\mathrm{N}=25)$ chickens at a commercial poultry processing plant. All samples were analysed for $\mathrm{pH}$, color values, shear force, cooking loss and desmin degradation at 0,4 and $24 \mathrm{~h}$ postmortem. The head only electrical stunning had significantly improved cooking loss and lightness $\left(\mathrm{L}^{*}\right)$ of the pectoralis major muscles. Besides, there was a tendency for the stunning regime employed in this experiment to cause more rapid degradation of desmin over the $24 \mathrm{~h}$ postmortem storage.
\end{abstract}

Key words: Stunning, $\mathrm{pH}$, color, shear force, cooking loss, desmin, chicken

\section{INTRODUCTION}

The employment of stunning in poultry processing plant is common as it promotes ease of slaughtering process hence, implicated in speedy mass processing production to meet the demand of human consumption. Besides, stunning lessens the pain that animals suffer during bleeding thus signify humane process which is highly concerned (Blokhuis et al., 2003). By preventing struggle at death, it also helps to delay rigor development but this slowing-effect cause a longer time of aging before deboning process can be done to ensure minimal shortening which is detrimental for quality (Sams, 1999). The mechanism of electrical stunning is to render unconsciousness and insensibility towards pain during exsanguinations by passing flow of current in animal's body to impede brains stimuli. However, electrical stunning often causes detrimental effects on carcass quality as incidence of red wing tips, hemorrhages and broken bones have been unacceptably high (Gregory and Wilkins, 1989; Northcutt et al., 1998).

Differences in meat quality traits are controlled by various factors, antemortem and postmortem. In previous studies, pre slaughter handling including stunning has significant attributes to the quality characteristics of the meat (Young and Buhr, 1997; Onenc and Kaya, 2004; Linares et al., 2006). The vast biochemical mechanisms and factors have been discussed in a way to approach meat quality, up to recent. It is agreeable that any factors which alter the onset of rigor may have indirect relationship towards tenderness and other quality traits.

Cytoskeletal system adopts a highly complex mechanism consists of a large number of connection between myofibrils and myofibrils as well as between myofibrils and sarcolemma (Kristensen, 2001). During conversion of muscle to meat, these complex connections are inevitably will be degraded by a number of proteolytic systems and this leads to changes of integrity and hydrophobicity of muscles proteins that may explained the variability in tenderness and juiciness of the meat (Koohmaraie, 1990; Kristensen, 2001; Maltin et al., 2003; Huff-Lonergan and Lonergan, 2005; Linares et al., 2006). Extensive studies have been made to investigate the role of calpains-calpastatin $\mathrm{Ca}^{2+}$ dependent degradation system as central to meat tenderization on multiple candidates of protein such as desmin, troponin- $\mathrm{T}$, nebulin, vinculin and titin (Koohmarie et al., 1991; Huff-Lonergan et al., 1996; Melody et al., 2004; Wojtysiak et al., 2008).

Stunning in Islam is not encouraged due to the doubts that the chicken may be killed or permanently injured by the procedure. Therefore, the National Fatwa Council of Malaysia has only allowed a specific range of amperage which results in reversible unconsciousness

Corresponding Author: A.Q. Sazili, Department of Animal Science, Faculty of Agriculture, Universiti Putra Malaysia, 43400 UPM Serdang, Selangor Darul Ehsan, Malaysia 
(MS 1500:2009, Department of Standards Malaysia). To the best of the knowledge such stunning procedure in poultry is yet to be scientifically investigated particularly in relation with changes in physico-chemical properties and proteolytic activity. Thus, the present study was conducted to determine the effects of head only water bath electrical stunning on physico-chemical characteristics and desmin degradation of broiler breast muscles at different time postmortem.

\section{MATERIALS AND METHODS}

The experiment and sampling: Commercially reared Cobb mixed-sex broilers, 42 days of age from a farm in Johor were transported to a commercial processing plant (Pertubuhan Peladang Negeri Johor, Machap, Johor, Malaysia). The entire handling, stunning, slaughtering and processing management were carried out according to the halal guidelines as outlined in the MS 1500:2009. The birds were kept in crates of 10 birds per crate during lairage (3-7 h) and randomly selected (live weight between $2.5-2.8 \mathrm{~kg}$ ) and shackled for $18-25 \mathrm{sec}$ prior to stunning. Before slaughter, the birds were randomly assigned to two groups ( $\mathrm{N}=25$ each) for pre-slaughter handlings. In the first group, the birds were slaughtered without prior stunning (US). The second group was stunned electrically using electrical water bath stunner (ES) at a constant voltage of $30 \mathrm{~V}, 0.2 \mathrm{~A}$ at approximately $50 \mathrm{~Hz}$ for $5 \mathrm{sec}$. Immediately after stunning, the birds were slaughtered by conventional method using a sharp knife to sever the trachea, esophagus and both the carotid arteries and jugular veins. Further processing of scalding and feather removal was carried out following the abattoir's operating procedure.

The whole pectoralis major muscle was filleted out of each dressed carcass. The left side of the muscle was used for shear force and desmin degradation analyses while the right half was assigned for color evaluation, $\mathrm{pH}$ and cooking loss determinations. All samples assigned for each analysis were further divided into three parts according to different time of Postmortem (PM) storage $(0,4$ and $24 \mathrm{~h})$. All samples were kept chilled in crushed ice until completion of their allotted PM storage time. For $\mathrm{pH}$ measurement and desmin degradation analysis, the samples were immediately plunged into liquid nitrogen and stored at $-80^{\circ} \mathrm{C}$ until subsequent analysis. As for the color, cooking loss and shear force analyses, samples were kept in labeled sealed polyethylene bag and blast frozen at $-80^{\circ} \mathrm{C}$ until analysis. All analyses were carried out at the Meat Science Laboratory, Department of Animal Science and Halal Products Research Institute, Universiti Putra Malaysia.
Muscle pH determination: The determination of muscle $\mathrm{pH}$ following to 0,4 and $24 \mathrm{~h}$ postmortem storage was carried out by first homogenizing $0.5 \mathrm{~g}$ of pulverized muscle tissue in $2 \mathrm{~mL}$ of deionized water in the presence of $150 \mathrm{mM} \mathrm{KCl}$ and $5 \mathrm{mM}$ sodium iodoacetate (Merck Schuchardt OHG, Germany). The use of sodium iodoacetate was to inhibit further glycolysis which if not stopped would have resulted in further decline of $\mathrm{pH}$ during the measurement. A glass electrode attached to a hand held $\mathrm{pH}$ meter (Mettler Toledo, USA) was used to measure $\mathrm{pH}$ of the resulted homogenates (Bendall, 1975).

Cooking loss determination: About $20 \mathrm{~g}$ of each sample was weighed, held in plastic bags and immersed in a water-bath preset at $80^{\circ} \mathrm{C}$ (Mermert $\mathrm{GmBH}$, Germany) and cooked until the internal temperature reached $78^{\circ} \mathrm{C}$. Then, the bags were cooled under running tap water for $30 \mathrm{~min}$ after which samples were removed and carefully dabbed dry with paper towels and reweighed. The percentage of cooking losses were then calculated from the difference between the weights where W1 is the weight of raw sample and W2 is the weight of cooked sample, the percentage of cooking loss was calculated using the following equation:

$$
\text { Cooking loss }(\%)=[(\mathrm{W} 1-\mathrm{W} 2) / \mathrm{W} 2] \times 100
$$

Shear force analysis (Volodkevitch bite jaw): At the end of each PM storage time $(0,4$ and $24 \mathrm{~h})$ the muscle samples were blast frozen and kept at $-80^{\circ} \mathrm{C}$ (Sanyo, Japan). Prior to the mechanical assessment of tenderness, the samples in vacuum bags were placed on a wellventilated rack and allowed to thaw overnight at $4^{\circ} \mathrm{C}$. The samples were then randomly cooked in water-bath to an internal temperature of $78^{\circ} \mathrm{C}$ and maintained at this temperature for an additional $10 \mathrm{~min}$. After cooking, samples were chilled overnight at $4^{\circ} \mathrm{C}$ before further preparation. The cooked samples were then cut parallel to the fiber direction into blocks with the dimension of each measured as $10 \times 10 \times 20 \mathrm{~mm}$. Each block was sheared once in the center and perpendicular to the longitudinal direction of the fibers using Volodkevitch bite jaw (stainless steel probe shaped like an incisor) which was fitted to a TA-HD plus texture analyzer (Stable Micro Systems, UK). The shear force values were reported as the mean of all replicates of samples.

Color determination: The color of pectoralis major muscle was measured using the ColorFlex ${ }^{\circledR}$ (HunterLab, USA) with illuminant D65 as the light source and $10^{\circ}$ standard observer (aperture opening size of $5 \mathrm{~cm}$ ). The instrument was calibrated against black and white reference tiles prior 
to use. The $\mathrm{L}^{*}$ (lightness), $\mathrm{a}^{*}$ (redness) and $\mathrm{b}^{*}$ (yellowness) color coordinate values were measured on the cut surface of muscle samples after a $30 \mathrm{~min}$ bloom time at $4^{\circ} \mathrm{C}$ (Hunter and Harold, 1987). Three measurements were taken from each sample and recorded as color coordinate values of each individual sample for 0,4 and $24 \mathrm{~h}$ PM.

Desmin immunoblot analysis: Approximately $1 \mathrm{~g}$ of initially pulverized muscle tissue were homogenized (Wiggen Hauser, Germany) in $3 \mathrm{~mL}$ ice cold extraction buffer ( $\mathrm{pH} 8.3$ ) containing $100 \mu$ MTris-base, $10 \mu \mathrm{M}$ EDTA and $0.05 \% \beta$-mercaptoethanol, $1 \mu \mathrm{mL}^{-1}$ of ProteoBlock ${ }^{\mathrm{TM}}$ protease inhibitor (ThermoScientific, USA) for $20 \mathrm{sec}$. The whole homogenates were centrifuged at $12,500 \mathrm{~g}$ for $15 \mathrm{~min}$ (at $4^{\circ} \mathrm{C}$ ). The resulted supernatant were collected and stored at $-20^{\circ} \mathrm{C}$ until subsequent analysis. Protein concentration determination was carried out using Bio Rad protein assay kit following the manufacturer's protocol (BioRad, USA). One volume of each supernatant was diluted in 2 volume of denaturing buffer and heated at $95^{\circ} \mathrm{C}$ for $4 \mathrm{~min}$. Samples with equal amount of total protein $(25 \mu \mathrm{g})$ were loaded into each respective well of $10 \%$ resolving SDS-PAGE (Bio-Rad Mini Protean ${ }^{\circledR}$ Tetra Cell) and electrophoresed at $120 \mathrm{~V}$ for $1 \mathrm{~h}$. The separated proteins were then transferred onto a $0.2 \mu \mathrm{m}$ Polyvinylidenedifluoride (PVDF) membrane (Bio-Rad, USA) using Trans-Blot SD Semi-Dry (Bio Rad, USA) transfer system at $250 \mathrm{~mA} / \mathrm{gel}$ for $30 \mathrm{~min}$. The blots were initially blocked with 5\% Bovine Serum Albumin (BSA) (Cat No: A7906, Sigma, USA) in TBST for $2 \mathrm{~h}$ at room temperature followed by incubation with 1:5000 primary antibody in 3\% BSA+TBST (monoclonal anti-desmin antibody; Cat No: D1033, Sigma, USA) for $1 \mathrm{~h}$. Membranes were washed with TBST three times; $5 \mathrm{~min}$ for each wash followed by incubation with 1:15000 dilution of secondary antibody (anti-mouse IgG whole molecule conjugated with alkaline phosphatase; Cat No: A3562, Sigma, USA) in 3\% BSA+TBST followed by three times of washing and were detected using AP Detection kit (Bio-Rad, USA). Protein bands were visualized and quantified using a gel densitometer (GS-800 Densitometer, Bio Rad, USA).

Data analysis: The distribution of the data was assessed based on Shiporo-Wilk's normality test and data were analysed using General Linear Models (GLM) procedure of SAS ${ }^{\circledR}$ Software (SAS, Version 9.1). The differences between means were determined using Duncan's multiple range test at significance level of $\mathrm{p}<0.05$.

\section{RESULTS AND DISCUSSION}

Muscle pH: The data for $\mathrm{pH}$ measurement are as shown in Table 1. There were no significant differences $(p>0.05)$ in muscle $\mathrm{pH}$ between US and ES groups across 0,4 and $24 \mathrm{~h}$ PM storage. Although not significant, the $\mathrm{pH}$ values indicated by the ES group were found to be numerically lower than the US samples and the trend appeared to be consistent over the $24 \mathrm{~h}$ PM storage (Table 1). Within the US group, significant differences in $\mathrm{pH}(\mathrm{p}<0.05)$ were noted between 0 and $4 \mathrm{~h}(6.00 \pm 0.04$ vs. $5.83 \pm 0.04)$ and between 0 and $24 \mathrm{~h}(6.00 \pm 0.04$ vs. $5.80 \pm 0.05) \mathrm{PM}$. Similarly, in the ES group, $\mathrm{pH}$ values differed significantly ( $<<0.05)$ between 0 and $4 \mathrm{~h}(5.94 \pm 0.05$ vs. $5.82 \pm 0.04)$ and between 0 and $24 \mathrm{~h}(5.94 \pm 0.05$ vs. $5.74 \pm 0.05) \mathrm{PM}$ (Table 1 ). Besides showing significant declines in muscle $\mathrm{pH}$ over the $24 \mathrm{~h}$ PM storage, the present results also suggest an earlier completion of rigor development at $4 \mathrm{~h}$ PM regardless the type of treatments employed to the birds.

The anaerobic glycolysis occurs upon depletion of $\mathrm{O}_{2}$ supply to tissues and this leads to the accumulation of lactic acid in the skeletal muscles which consequently result in $\mathrm{pH}$ decline. In contrast, previous studies in commercial broiler chickens have documented higher $\mathrm{pH}$ values in pectoral muscle following pre slaughter stunning and the findings were explained by death struggle observed in the birds that received no electrical stunning (Papinaho et al., 1995; Young and Buhr, 1997; Poole and Fletcher, 1998; Sams, 1999; Alvarado and Sams, 2000; Contreras and Beraquet, 2001). In the study, the absence of significant difference in $\mathrm{pH}$ values between the treatments could possibly be explained by the lower amperage and duration settings employed. Despite numerous studies conducted previously, the findings on the effects of stunning on muscle $\mathrm{pH}$ are rather inconsistent due to differences in the stunning parameters used. This can be further supported by Papinaho et al. (1995) who documented higher muscle $\mathrm{pH}$ values with increasing amperage in the electrically stunned birds.

Muscle color values: In this experiment, only the $L^{*}$ values were significantly $(p<0.001)$ affected by the

Table 1: Differences in muscle pH values between ES and US at 0,4 and $24 \mathrm{~h}$ PM time

\begin{tabular}{|c|c|c|c|c|c|c|}
\hline \multirow[b]{2}{*}{ Parameters } & \multirow[b]{2}{*}{$\begin{array}{r}\text { PM } \\
\text { (h) }\end{array}$} & \multirow[b]{2}{*}{$\begin{array}{c}\text { US } \\
(\mathrm{N}=25)\end{array}$} & \multirow[b]{2}{*}{$\begin{array}{c}\mathrm{ES} \\
(\mathrm{N}=25)\end{array}$} & \multicolumn{3}{|c|}{ Significance } \\
\hline & & & & Stun & Time & Stun $x$ time \\
\hline \multirow[t]{3}{*}{ pH (unit) } & 0 & $6.00 \pm 0.04^{x}$ & $5.94 \pm 0.05^{x}$ & NS & $<0.001$ & NS \\
\hline & 4 & $5.83 \pm 0.04 \mathrm{y}$ & $5.82 \pm 0.04$ & - & - & - \\
\hline & 24 & $5.80 \pm 0.05^{\mathrm{y}}$ & $5.74 \pm 0.05^{y}$ & - & - & - \\
\hline
\end{tabular}

$\overline{x, y}$ Means within a column with different superscripts are significantly different at $\mathrm{p}<0.05 ; \mathrm{US}=\mathrm{Un}$-Stunned; ES = Electrically Stunned; NS $=$ Not Significant 
treatments (Table 2 ). The $\mathrm{L}^{*}$ values appeared to be lower $(p<0.001)$ in the muscle samples taken from the ES than those from the US birds and these were consistently observed across $0(47.32 \pm 0.65$ vs. $50.38 \pm 0.61), 4(49.03 \pm$ 0.77 vs. $52.74 \pm 0.72$ ) and $24 \mathrm{~h} 55.67 \pm 0.84$ vs. $59.14 \pm 0.79$ ) PM storage (Table 2). The $\mathrm{a}^{*}$ and $\mathrm{b}^{*}$ values were however found to be unaffected ( $>>0.05$ ) by the stunning treatment employed in this study. In the case of lightness, the L* values were significantly elevated with time of storage and these were encountered in US $(50.38 \pm 0.61$ at $0 \mathrm{~h}$; $52.74 \pm 0.72$ at $4 \mathrm{~h}, 59.14 \pm 0.79$ at $24 \mathrm{~h})$ and $\mathrm{ES}(47.32 \pm 0.65$ at $0 \mathrm{~h} ; 49.03 \pm 0.77$ at $4 \mathrm{~h}, 55.67 \pm 0.84$ at $24 \mathrm{~h}$ ) (Table 2). In contrast, the redness $\left(a^{*}\right)$ and yellowness $\left(b^{*}\right)$ values declined with increasing time of post mortem storage (Table 2). In comparison with 0 and $4 \mathrm{~h}$ post mortem, significant decline $(\mathrm{p}<0.001)$ in both $\mathrm{a}^{*}$ and $\mathrm{b}^{*}$ values were only encountered at $24 \mathrm{~h}$ post mortem and these appeared to be consistently present in both treatment groups (Table 2).

Earlier, birds subjected to electrical stunning indicated lower lightness as compared to the un-stunned ones (Young and Buhr, 1997; Craig and Fletcher, 1997). The increased lightness in meat with increasing post mortem storage duration has been associated with proteins degradation and shrinkage of myofibrils which in turn may weaken their water holding capacity and consequently resulted in enhanced light scattering (Alvarado and Sams, 2000). Abnormally high L* values which are usually encountered in Pale, Soft, Exudative (PSE) meat had always been associated with acute stress that causes a more rapid glycogen depletion and accelerated rigor development (Barbut, 1998; Channon et al., 2002; Onenc and Kaya, 2004).

Previous findings on the effects of electrical stunning on the $a^{*}$ and $b^{*}$ values of breast muscles have not been consistent. Craig et al. (1999) recorded significantly

Table 2: Differences in meat color $\left(L^{*}, a^{*}\right.$ and $\left.b^{*}\right)$ values between ES and US at 0,4 and $24 \mathrm{~h}$ PM time

\begin{tabular}{|c|c|c|c|c|c|c|}
\hline \multirow[b]{2}{*}{ Parameters } & \multirow[b]{2}{*}{$\begin{array}{r}\text { PM } \\
\text { (h) }\end{array}$} & \multirow[b]{2}{*}{$\begin{array}{c}\mathrm{US} \\
(\mathrm{N}=25)\end{array}$} & \multirow[b]{2}{*}{$\begin{array}{c}E S \\
(\mathbb{N}=25)\end{array}$} & \multicolumn{3}{|c|}{ Significance } \\
\hline & & & & Stun & Time & Stun $\mathrm{x}$ time \\
\hline Lightness & 0 & $50.38 \pm 0.61^{\mathrm{az}}$ & $47.32 \pm 0.65^{b z}$ & $<0.001$ & $<0.001$ & NS \\
\hline \multirow[t]{2}{*}{$\left(\mathrm{L}^{*}\right)$} & 4 & $52.74 \pm 0.72^{\text {ay }}$ & $49.03 \pm 0.77^{\text {by }}$ & & & \\
\hline & 24 & $59.14 \pm 0.79^{\mathrm{ax}}$ & $55.67 \pm 0.84^{b x}$ & & & \\
\hline \multirow{3}{*}{$\begin{array}{l}\text { Redness } \\
\left(a^{*}\right)\end{array}$} & 0 & $3.98 \pm 0.28^{x}$ & $4.39 \pm 0.30^{x}$ & NS & $<0.001$ & NS \\
\hline & 4 & $3.92 \pm 0.21^{x}$ & $4.07 \pm 0.22^{x}$ & & & \\
\hline & 24 & $2.46 \pm 0.25^{y}$ & $2.31 \pm 0.23^{y}$ & & & \\
\hline \multirow{3}{*}{$\begin{array}{l}\text { Yellowness } \\
\left(\mathrm{b}^{*}\right)\end{array}$} & 0 & $16.73 \pm 0.37^{x}$ & $16.51 \pm 0.40^{x}$ & NS & $<0.001$ & NS \\
\hline & 4 & $16.35 \pm 0.33^{x}$ & $16.33 \pm 0.35^{x}$ & & & \\
\hline & 24 & $12.57 \pm 0.56^{\mathrm{y}}$ & $12.22 \pm 0.60^{\mathrm{y}}$ & & & \\
\hline
\end{tabular}

\footnotetext{
${ }^{\mathrm{a}, \mathrm{b}}$ Means within a row with different superscripts are significantly different at $\mathrm{p}<0.05$; ${ }^{\mathrm{x}-2}$ Means within a column with different superscripts are significantly different at $\mathrm{p}<0.05$; US = Un-Stunned; ES = Electrically Stunned; NS $=$ Not Significant
}

higher $a^{*}$ values and lower $b^{*}$ values in breast muscle samples obtained from electrically stunned birds while Young and Buhr (1997) found no difference in $a^{*}$ values regardless the duration of stunning adopted but significantly higher $b^{*}$ values were only noticed in the birds assigned to $10 \mathrm{sec}$ of electrical stunning. Mohan et al. (1990) relates meat discoloration with bleeding time in which shorter bleeding time in electrical stunned birds led to redder meat appearance by the reported higher heme levels.

Shear force values: In this study, the application of electrical stunning did not cause any effects $(p>0.05)$ on the shear force values of broiler chickens breast muscles at all times PM. At pre rigor ( $0 \mathrm{~h} \mathrm{PM})$, the shear force values for the US and ES groups were $1.61 \pm 0.10$ and $1.66 \pm 0.10 \mathrm{~kg}$, respectively (Table 3 ). Similarly, the differences in shear force values between US and ES groups at $4 \mathrm{~h}(1.55 \pm 0.08$ vs. $1.41 \pm 0.08 \mathrm{~kg})$ and $24 \mathrm{~h}$ (1.19 \pm 0.07 vs. $1.32 \pm 0.07)$ PM were also not significant ( $>0.05$; Table 3 ). However within each group, differences in shear force values $(\mathrm{p}<0.05)$ were noted across 0,4 and $24 \mathrm{~h}$ PM (Table 3 ). In the US birds, significant differences in shear force values appeared between 0 and $24 \mathrm{~h}$ $(1.61 \pm 0.10$ vs. $1.19 \pm 0.07)$ and between 4 and $24 \mathrm{~h}$ (1.55 \pm 0.08 vs. $1.19 \pm 0.07$ ) PM (Table 3). Meanwhile in the case of ES, the differences were observed between $0 \mathrm{~h}$ and $4 \mathrm{~h}(1.66 \pm 0.10$ vs. $1.41 \pm 0.08)$ and between $0 \mathrm{~h}$ and $24 \mathrm{~h}(1.66 \pm 0.10$ vs. $1.32 \pm 0.07) \mathrm{PM}$ samples. The results demonstrated significant improvement $(p<0.05$; Table 3$)$ in cooked breast muscle tenderness in both US and ES groups with increasing PM storage time.

In both groups, the highest force required to perpendicularly shear the muscle fibers was observed at $0 \mathrm{~h}$ PM. The phenomena of initial toughening of skeletal muscles during the early phase of rigor development have been closely associated with the event called cold shortening. Although, broiler pectoralis major muscles were mainly composed of white fibres (Dranfield and

Table 3: Differences in shear force values and cooking loss between ES and US at 0,4 and $24 \mathrm{~h}$ PM time

\begin{tabular}{|c|c|c|c|c|c|c|}
\hline \multirow[b]{2}{*}{$\underline{\text { Parameters }}$} & \multirow[b]{2}{*}{$\begin{array}{l}\text { PM } \\
\text { (h) }\end{array}$} & \multirow[b]{2}{*}{$\begin{array}{c}\text { US } \\
(\mathrm{N}=25)\end{array}$} & \multirow[b]{2}{*}{$\begin{array}{c}E S \\
(N=25)\end{array}$} & \multicolumn{3}{|c|}{ Significance } \\
\hline & & & & Stun & Time & Stun $\mathrm{x}$ time \\
\hline \multirow{3}{*}{$\begin{array}{l}\text { Shear force } \\
(\mathrm{kg})\end{array}$} & 0 & $1.61 \pm 0.100^{\mathrm{x}}$ & $1.66 \pm 0.10^{x}$ & NS & $<0.001$ & NS \\
\hline & 4 & $1.55 \pm 0.08^{x}$ & $1.41 \pm 0.08^{y}$ & & & \\
\hline & 24 & $1.19 \pm 0.07^{\mathrm{y}}$ & $1.32 \pm 0.07 \mathrm{y}$ & & & \\
\hline \multirow{3}{*}{$\begin{array}{l}\text { Cooking loss } \\
(\%)\end{array}$} & 0 & $23.15 \pm 0.550^{x}$ & $21.58 \pm 0.56^{x}$ & $<0.05$ & $<0.001$ & $<0.001$ \\
\hline & 4 & $23.07 \pm 0.510^{\mathrm{ax}}$ & $18.61 \pm 0.52^{\text {by }}$ & & & \\
\hline & 24 & $20.13 \pm 0.560^{\text {ay }}$ & $21.86 \pm 0.57^{\mathrm{bx}}$ & & & \\
\hline
\end{tabular}

a, beans within a row with different superscripts are significantly different at $\mathrm{p}<0.05 ; \mathrm{x}, \mathrm{y}$ Means within a column with different superscripts are significantly different at $\mathrm{p}<0.05$; US $=$ Un-Stunned; $\mathrm{ES}=$ Electrically Stunned; NS = Not Significant 
Sosnicki, 1999) which made them less susceptible to cold shortening than compared to red meat species, previous studies succeed to discover the occurrence of the event (Wood and Richards, 1974; Bilgili et al., 1989; Sams, 1999). The onset and extent of PM proteolysis as rigor is completed determine the subsequent meat tenderization (Maltin et al., 2003). Thus, the entire processes during muscle to meat conversion could possibly explain by the delay in the appearance of significant changes in shear force until $24 \mathrm{~h} \mathrm{PM}$.

Previous results in relation to the effects of pre slaughter stunning on shear force values in broiler chickens are rather inconsistent. Papinaho and Fletcher (1995) and Northcutt et al. (1998) reported that the application of electrical stunning did not affect the meat tenderness while Young and Buhr (1997), reported significantly tougher poultry meat following to electrical stunning while Lee et al. (1979) observed higher shear force values only after $4 \mathrm{~h}$ aging. Additionally, Lee et al. (1979) who reported 30\% improved poultry meat tenderness of the electrically stunned birds at $24 \mathrm{~h} \mathrm{PM}$ associated with the findings of higher ATP, $\mathrm{CP}$ and $\mathrm{pH}$ values suggested that ES application delays the onset of rigor development explaining by the deceleration of $\mathrm{pH}$ decline. The inconsistent findings may be explained by differences in current and voltage inputs, resistance and duration of stunning regimes employed between studies (Papinaho and Fletcher, 1995; Craig and Fletcher, 1997; Young and Buhr, 1997).

Cooking loss: In this study, the presence of interaction $(\mathrm{p}<0.001)$ between stunning and storage time suggested that the effects of stunning $(\mathrm{p}<0.05)$ on cooking loss was also time dependent (Table 3). Apparently, significant differences in cooking loss between the treatment groups were only present at 4 and $24 \mathrm{~h} \mathrm{PM}$ (Table 3 ). At $4 \mathrm{~h} \mathrm{PM}$, higher cooking loss was indicated by the breast muscle samples collected from the US $(23.07 \pm 0.51)$ than those from the ES (18.61 \pm 0.52$)$ group. In contrast, at $24 \mathrm{~h} \mathrm{PM}$ storage, ES (21.86 \pm 0.57$)$ has exhibited higher cooking loss than the samples of US $(20.13 \pm 0.56)$. Similarly, the significant differences $(\mathrm{p}<0.001)$ noted between the 0,4 and $24 \mathrm{PM}$ times were also dependent on the treatments (Table 3). Within the US group, significant differences in cooking loss were seen between $0(23.15 \pm 0.55)$ and $24 \mathrm{~h}$ $(20.13 \pm 0.56)$ and between $4(23.07 \pm 0.51)$ and $24 \mathrm{~h}$ $(20.13 \pm 0.56) \mathrm{PM}$ with no difference was seen between 0 $(23.15 \pm 0.55)$ and $4 \mathrm{~h}(23.07 \pm 0.51) \mathrm{PM}$. The results indicated a significant decline in percentage of cooking loss at $24 \mathrm{~h} \mathrm{PM}$ relative to 0 and $4 \mathrm{~h}$ PM (Table 3). However in the case of ES group, significant differences in cooking loss only appeared between $0(21.58 \pm 0.56)$ and
$4 \mathrm{~h}(18.61 \pm 0.52)$ and between $4(18.61 \pm 0.52)$ and $24 \mathrm{~h}$ (21.86 \pm 0.57$)$ PM. Unlike the US group, there was no difference $(p>0.05$; Table 3$)$ in cooking loss between the samples subjected to $0 \mathrm{~h}(21.58 \pm 0.56)$ and $24 \mathrm{~h}$ (21.86 \pm 0.57$) \mathrm{PM}$ storage. In relation with the absence of difference in cooking loss between 0 and $4 \mathrm{~h}$ in the US samples, the significantly lower $(\mathrm{p}<0.001$; Table 3$)$ cooking loss in the $4 \mathrm{~h}(18.61 \pm 0.52)$ compared to the $0 \mathrm{~h}$ (21.58 \pm 0.56$) \mathrm{PM}$ samples of the ES group suggested that the stunning method employed in the current study has resulted in a more rapid decline in cooking loss. However, compared to $4 \mathrm{~h}(18.61 \pm 0.52)$ post mortem, the percentage of cooking loss was found to be significantly increased at $24 \mathrm{~h}(21.86 \pm 0.57) \mathrm{PM}$.

Water holding capacity of a muscle can be examined through analysis such as cooking loss, centrifugation loss, compression loss and cutting and mincing loss. Water component in skeletal muscles can be in three identities. There are identified as free water, bound water and immobilized water. The free water is the water component that is passively purged out of a muscle without the influence of protein structure. The bound water has reduced mobility and is very resistant to freezing and evaporation by heat. This water changes very little in post rigor muscles. The immobilized water is held either by steric effects or attraction to the bound water and held within the structure of the muscle but not bound to proteins.

The improved water holding capacity (as indicated by reduced cooking loss) observed at $24 \mathrm{~h}$ (in US group) and $4 \mathrm{~h}$ (in ES group) PM could be due to the proteolytic degradation of cytoskeletal proteins which may subsequently cause swelling of the myofibrils and allowed the meat to retain more water. It has been hypothesized that degradation of the cytoskeleton during ageing would increase water holding capacity of meat by removing inter-myofibrillar and costameric connections and thereby reduce or remove the linkage between the rigor-induced lateral shrinkage of myofibrils and shrinkage of the whole muscle fiber. The inflow of extracellular water to the muscle cell after the cytoskeletal protein has been degraded may be caused by the difference in protein concentration which exists between intra and extracellular compartments (Kristensen, 2001).

The increase in water holding capacity as indicated by a significant decline in cooking loss of the un-stunned samples at $24 \mathrm{~h}$ post mortem could be caused by a decrease in the total water content of the meat (Huff-Lonergan and Lonergan, 2005). During the development or rigor, the diameter of muscle cells has been shown to decrease (Swatland and Belfry, 1985) and is likely the result of transmittal of the lateral shrinkage of 
the myofibrils to the entire cells (Diesbourg et al., 1988). Additionally, during rigor development sarcomere can shorten, this also reduces the space available for water within the myofibril. In fact, it has been shown that drip loss can increase linearly with a decrease in the length of the sarcomeres in muscle cell (Honikel et al., 1986). However, there were variably inconsistent findings among previous reports on the effect of electrical stunning on water holding capacity. Insignificant difference between ES and US was demonstrated in Papinaho and Fletcher (1995), Young and Buhr (1997) and Northcutt et al. (1998) and negative effect of ES was detected in bulls (Onenc and Kaya, 2004) and lamb (Linares et al., 2006). Hence, the data suggest that the improved WHC could be due to acceleration of rigor development as early $4 \mathrm{~h}$ by the stunning method employed in this study.

Desmin degradation: The differences in the immunoreactivities of 54,49 and $39 \mathrm{kDa}$ desmin in pectoralis major muscles between the electrically stunned and un-stunned broiler chickens and at different time post mortem are as shown in Table 4 while a representative blot is as shown in Fig. 1. The expression of $54 \mathrm{kDa}$ desmin was found to be unaffected by the stunning treatment employed in this study and these were consistently observed at 0,4 and $24 \mathrm{~h} \mathrm{PM}$. However, significant differences in the immunoreactivity of $54 \mathrm{kDa}$ desmin were seen between 0,4 and $24 \mathrm{~h} \mathrm{PM}$. The results indicate a

Table 4: Differences in immunoreactivities of desmin (at 54, 49 and $39 \mathrm{kDa}$ ) between US and ES at 0, 4 and $24 \mathrm{~h}$ PM time

\begin{tabular}{|c|c|c|c|c|c|c|}
\hline \multirow[b]{2}{*}{ Parameters } & \multirow[b]{2}{*}{$\begin{array}{l}\text { PM } \\
\text { (h) }\end{array}$} & \multirow{2}{*}{$\begin{array}{c}\text { US } \\
(\mathrm{N}=10)\end{array}$} & \multirow[b]{2}{*}{$\begin{array}{c}\text { ES } \\
(N=10)\end{array}$} & \multicolumn{3}{|c|}{ Significance } \\
\hline & & & & Stun & Time & Stun $x$ time \\
\hline \multirow[t]{3}{*}{ Desmin 54} & 0 & $203.14 \pm 25.60$ & $215.31 \pm 19.83$ & NS & $<0.05$ & NS \\
\hline & 4 & $188.73 \pm 32.44$ & $206.44 \pm 25.13$ & & & \\
\hline & 24 & $157.86 \pm 28.80$ & $175.65 \pm 22.31$ & & & \\
\hline \multirow[t]{3}{*}{ Desmin 49} & 0 & $0.77 \pm 0.120^{y}$ & $0.13 \pm 0.380^{y}$ & NS & $<0.001$ & NS \\
\hline & 4 & $10.09 \pm 6.420^{\mathrm{y}}$ & $2.12 \pm 4.970^{y}$ & & & \\
\hline & 24 & $59.77 \pm 12.17^{x}$ & $32.99 \pm 9.430^{\circ}$ & & & \\
\hline \multirow[t]{3}{*}{ Desmin 39} & 0 & $3.76 \pm 2.010^{y}$ & $0.02 \pm 1.360^{y}$ & NS & $<0.001$ & NS \\
\hline & 4 & $12.17 \pm 5.040^{y}$ & $4.62 \pm 3.400^{\mathrm{y}}$ & & & \\
\hline & 24 & $42.25 \pm 12.74^{x}$ & $26.63 \pm 8.590^{x}$ & & & \\
\hline
\end{tabular}

${ }_{a}^{a b}$ Means within a row with different superscripts are significantly different at $\mathrm{p}<0.05$; ${ }^{x}$,Means within a column with different superscripts are significantly different at $\mathrm{p}<0.05$; US $=$ Un-Stunned; $\mathrm{ES}=$ Electrically Stunned; NS $=$ Not Significant

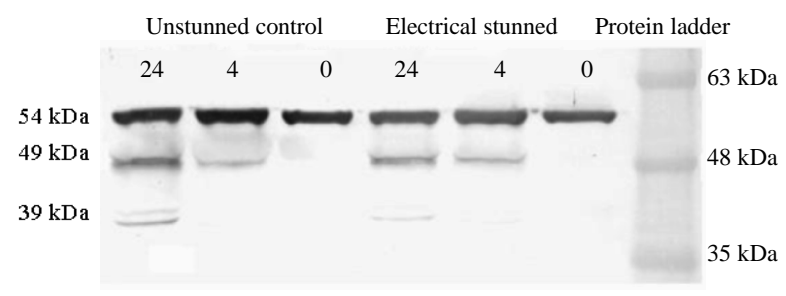

Fig. 1: Representative blot of desmin in the US and ES samples at different time PM significant effect of time PM on the expression of $54 \mathrm{kDa}$ desmin. The immunoreactivity declined significantly with increasing time of post mortem storage and these were noted in both un-stunned and electrically stunned samples. Similar to the $54 \mathrm{kDa}$ isoform, the expression of 49 and $39 \mathrm{kDa}$ desmin also remained unaffected by the stunning treatment with significant differences seen between 0,4 and $24 \mathrm{~h} \mathrm{PM}$. Unlike the $54 \mathrm{kDa}$ native isoform, the immunoreactivity of 49 and $39 \mathrm{kDa}$ desmin increased significantly over the $24 \mathrm{~h}$ PM storage. The present data suggest occurrence of post mortem proteolysis of the $54 \mathrm{kDa}$ desmin which in turn has resulted in the presence and increasing expression of the 49 and $39 \mathrm{kDa}$ desmin across the $24 \mathrm{~h} \mathrm{PM}$. However, the significant differences $(\mathrm{p}<0.05)$ were only seen between 0 and $24 \mathrm{~h}$ and between 4 and $24 \mathrm{~h} \mathrm{PM}$ (Table 4).

In general, although not significant, the immunoreactivity of $54 \mathrm{kDa}$ desmin appeared to be numerically higher in the stunned birds and these were consistently seen at 0,4 and $24 \mathrm{~h} \mathrm{PM}$. In contrast, the immunoreactivities of the degraded forms of desmin (49 and $39 \mathrm{kDa}$ ) was found to be numerically higher in the US (Table 4). The results suggest more rapid and extensive degradation of desmin in the US compared to the ES samples. Speculatively, the method of pre slaughter stunning employed in this study could have delayed and minimized the degradation of cytosketelal proteins as indicated by lower immunoreactivity of 49 and $39 \mathrm{kDa}$ desmin in the treated birds particularly at 4 and $24 \mathrm{~h} \mathrm{PM}$. Wojtysiak et al. (2008) illustrated a gradual degradation of desmin over the first $24 \mathrm{~h}$ of post mortem storage.

Previous studies have shown that cytoskeletal and other structural proteins like desmin are degraded during ageing of meat and the resulted proteolysis has been associated with changes in meat quality particularly tenderness and water holding capacity via post mortem proteolysis (Koohmarie et al., 1991; Maltin et al., 2003; Melody et al., 2004). The degradation of intermediate filaments may tenderize meat by facilitating the separation of myofibrils, thereby weakening the lateral strength of meat. Three different systems involved in skeletal muscle proteolysis are lysosomal cathepsin, calpain and proteasome (Adenosine Triphosphate (ATP)/ubiquitin dependent) systems (Dranfield and Sosnicki, 1999). Desmin degradation has been associated with $\mathrm{pH}$, water holding capacity and tenderness (Northcutt et al., 1998; Koohmaraie, 1990). In addition, the highest correlation between desmin degradation and $\mathrm{pH}$, drip loss and shear force values was observed at $15 \mathrm{~min}$ and $24 \mathrm{~h} \mathrm{PM}$ (Wojtysiak et al., 2008). As presented (Table 4), the intensity of intact desmin was significantly decrease while 
degraded products of desmin was proportionately increase with time PM although poultry meat is categorized as white muscle which contains smaller number of desmin proteins than red muscle animal.

The numerically higher proteolytic activity in ES samples was in contrast with the findings by Northcutt et al. (1998) which found the highest m-calpain activity in $7 \mathrm{sec}, 200 \mathrm{~mA}$ electrically stunned followed by gas stunning and un-stunned treatments in turkeys. There, it could be speculated that electrical stunning regime employed in this study may have channeled type of stress that causes body to react against stresses hence may alter the final meat quality. Desmin and titin are cytoskeletal proteins that are found in the costamere and are non-resistant to digestion by both $\mathrm{u}$ and m-calpain (Koohmarie et al., 1991). As pH decline, u-calpains activity become activated, acting on the sarcolemma membrane then releasing $\mathrm{Ca}^{2+}$ to extracellular space, later then initiated m-calpains system. Desmin dissociation from costameres are often regarded in the improved tenderness and juiciness (Kristensen, 2001). Nevertheless, despite desmin degradation over post mortem times, the significant differences between the treatments may not be strong enough to imply that the stunning regime employed in this study had slowing-effect on rigor development.

Previous studies have shown that desmin and other cytoskeletal proteins are degraded during storage of meat with the dissociation of desmin from costameres often regarded to increase tenderness and juiciness (Koohmarie et al., 1991; Kristensen, 2001; Melody et al., 2004). In this study, desmin expression, meat $\mathrm{pH}$, colour values and shear force values were all not affected by the application of electrical stunning in commercial broiler chickens. Nevertheless, pre-slaughter stunning has significantly affected the meat cooking loss with the influence of time.

The cooking loss of the stunned samples was significantly reduced suggesting a significant improvement in water holding capacity of the stunned broiler chicken samples at $4 \mathrm{~h}$ PM. Similar improvement in water holding capacity as indicated by a significant decrease in cooking loss only appeared later (at $24 \mathrm{~h} \mathrm{PM}$ ) in the US samples. This could suggest a more rapid rigor development which could have occurred in the samples obtained from the stunned birds. In general, post mortem proteolysis reflected by the temporal changes in the expression of 49 and $39 \mathrm{kDa}$ desmin encountered in both treatment groups (US and ES) may explain the trend of improving tenderness as indicated by the decrease in shear force values. Besides, degradation of desmin could also be associated with the trend of decreasing cooking loss over $24 \mathrm{~h} \mathrm{PM}$ in both groups.

\section{CONCLUSION}

From the results presented in this study, it is clearly demonstrated that the application of the water bath head only electrical stunning in commercial broiler chickens has significantly improved water holding capacity of the cooked breast muscles earlier compared to those unstunned. Despite having no effects on meat $\mathrm{pH}$ and tenderness, the patterns of desmin degradation $>24 \mathrm{~h} \mathrm{PM}$ storage suggests a more rapid and extensive proteolysis which could have occurred in the electrically stunned samples. Thus, it can be concluded that the head only electrical stunning employed in this experiment could have potentially enhanced proteolysis and lightness of the meat.

\section{REFERENCES}

Alvarado, C.Z. and A.R. Sams, 2000. Rigor mortis development in turkey breast muscle and the effect of electrical stunning. Poult. Sci., 79: 1694-1698.

Barbut, S., 1998. Estimating the magnitude of the PSE problem in young turkey breast meat. Can. J. Anim. Sci., 76: 455-457.

Bendall, J.R., 1975. Cold contracture and ATP-turnover in the red and white musculature of the pig post mortem. J. Sci. Food Agric., 26: 55-71.

Bilgili, S.F., W.R. Egbert and D.L. Huffman, 1989. Effect of postmortem aging temperature on sarcomere length and tenderness of broiler Pectoralis major. Poult. Sci., 68: 1588-1591.

Blokhuis, H.J., R.B. Jones, R. Geers, M. Miele and I. Veissier, 2003. Measuring and monitoring animal welfare: Transparency in the food product quality chain. Anim. Welfare, 12: 445-455.

Channon, H.A., A.M. Payne and R.D. Warner, 2002. Comparison of $\mathrm{CO} 2$ with manual electrical stunning $(50 \mathrm{~Hz})$ of pigs on carcass and meat quality. Meat Sci., 60: 63-68.

Contreras, C.C. and N.J. Beraquet, 2001. Electrical stunning, hot boning and quality of chicken breast meat. Poult. Sci., 80: 501-507.

Craig, E.W. and D.L. Fletcher, 1997. A comparison of high current and low voltage electrical stunning systems on broiler breast rigor development and meat quality. Poult. Sci., 78: 1178-1181.

Craig, E.W., D.L. Fletcher and P.A. Papinaho, 1999. The effects of antemortem electrical stunning and postmortem electrical stimulation on biochemical and textural properties of broiler breast. Poult. Sci., 78: 490-494. 
Diesbourg, L., H.J. Swatland and B.M. Millman, 1988. Xray-diffraction measurements of postmortem changes in the myofilament lattice of pork. J. Anim. Sci., 66: 1048-1054.

Dranfield, E. and A.A. Sosnicki, 1999. Relationship between muscle growth and poultry meat quality. Poultry Sci., 78: 743-746.

Gregory, N.G. and L.J. Wilkins, 1989. Effect of stunning current on downgrading in turkeys. Br. Poult. Sci., 30: 761-764.

Honikel, K.O., C.J. Kim and R. Hamm, 1986. Sarcomere shortening of pre-rigor muscle and its influence on drip loss. Meat Sci., 16: 267-282.

Huff-Lonergan, E. and S.M. Lonergan, 2005. Mechanisms of water-holding capacity of meat: The role of postmortem biochemical and structural changes. Meat Sci., 71: 194-204.

Huff-Lonergan, E., T. Mitsuhashi, D.D. Beekman, F.C. Parrish, J. Dennis, D.G. Olson and R.M. Robson, 1996. Proteolysis of specific muscle structural proteins by $\mathrm{u}$-calpain at low $\mathrm{pH}$ and temperature is similar to degradation in postmortem bovine muscle. J. Anim. Sci., 74: 993-1008.

Hunter, R.S. and R.W. Harold, 1987. The Measurement of Appearance. 2nd Edn., Wiley-Interscience, New York, pp: 432.

Koohmaraie, M., 1990. Quantitation of $\mathrm{Ca}^{2+}$ dependent protease activities by hydrophobic and ion-exchange chromatography. J. Anim. Sci., 68: 659-665.

Koohmarie, M., G. Whipple, D.H. Kretchmar, J.D. Crouse and J. Mersmann, 1991. Postmortem proteolysis in longisimus muscle from beef, lamb and pork carcasses. J. Anim. Sci., 69: 617-624.

Kristensen, L., 2001. The effect of ageing on the water holding capacity of pork: Role of cytoskeletal proteins. Meat Sci., 58: 17-23.

Lee, Y.B., G.L. Hargus, J.E. Webb, D.A. Rickansrud and E.C. Hagberg, 1979. Effect of electrical stunning on postmortem biochemical changes and tenderness in broiler breast muscle. J. Food Sci., 44: 1121-1128.

Linares, M.B., R. Bornez and H. Vergara, 2006. Effect of different stunning systems on meat quality of light lamb. Meat Sci., 76: 675-681.
Maltin, C., D. Balcerzak, R. Tilley and M. Delday, 2003. Determinants of meat quality: Tenderness. Proc. Nutr. Soc., 62: 337-347.

Melody, J.L., S.M. Lonergan, L.J. Rowe, T.W. Huiatt, M.S. Mayes and E. Huff-Lonergan, 2004. Early postmortem biochemical factors influence tenderness and water holding capacity of three porcine muscles. J. Anim. Sci., 82: 1195-1205.

Mohan, R.A.B., T.C. Grey, A.R. Audsley and N.G. Gregory, 1990. Effect of electrical and gaseous stunning on the carcass and meat quality of broilers. Br. Poult. Sci., 31: 725-733.

Northcutt, J.K., R.J. Buhr and L.L. Young, 1998. Influence of pre slaughter stunning on turkey breast muscle quality. Poult. Sci., 77: 487-492.

Onenc, A. and A. Kaya, 2004. The effects of electrical stunning and percussive captive bolt stunning on meat quality of cattle processed by Turkish slaughter procedures. Meat Sci., 66: 809-815.

Papinaho, P.A. and D.L. Fletcher, 1995. Effects of electrical stunning duration on post-mortem rigor development and broiler breast meat tenderness. J. Muscle Foods, 6: 1-8.

Papinaho, P.A., D.L. Fletcher and R.J. Buhr, 1995. Effect of electrical stunning amperage and peri-mortem struggle on broiler breast rigor development and meat quality. Poult. Sci., 74: 1533-1539.

Poole, G.H. and D.L. Fletcher, 1998. Comparison of a modified atmosphere stunning-killing system to conventional electrical stunning and killing on selected broiler breast muscle rigor development and meat quality attributes. Poult. Sci., 77: 342-347.

Sams, A.R., 1999. Meat quality during processing. Poult. Sci., 78: 798-803.

Swatland, H.J. and S. Belfry, 1985. Post mortem changes in the shape and size of myofibrils from skeletal muscle of pigs. Mikroskopie, 42: 26-26.

Wojtysiak, D., K. Poltowicz and J. Karasinski, 2008. Relationship between post mortem desmin degradation and meat quality of poultry breast muscle. Medycyna Weterynaryjna, 64: 1003-1006.

Wood, D.F. and J.F. Richards, 1974. Isometric tension studies on chicken Pectoralis major muscle. J. Food Sci., 39: 525-529.

Young, L.L. and R.J. Buhr, 1997. Effects of stunning duration on quality characteristics of early deboned chicken fillets. Poult. Sci., 76: 1052-1055. 